\title{
8 \\ Tempering power through networked governance
}

\section{Key propositions}

- Most good things accomplished in social life require the exercise of power. Among the things power helps accomplish are protecting freedom and preventing crime.

- Hence, we do not seek to limit or curb power, but to enable good power by tempering it.

- Untempered power dominates. It is not constrained by other powers from being arbitrary.

- Constitutions and their implementation are imperative conduits to power, to protecting freedom and to preventing crime.

- Constitutions enable tempered power by separating and balancing powers while also enabling power to be decisive. Decisiveness accomplishes specialised purposes of power efficiently and semiautonomously. Judicial power is decisive because judges, and only judges, can convict. Judges have clearly defined capacities to break gridlock between other separated powers because they have decisive powers. Conversely, it is the police officer, and not another judge, who has the power to arrest a judge for domestic violence, and a prosecutor who has the power to prosecute. Each power is channelled to its specialised purposes by checks and balances from other powers that prevent them from arbitrarily breaking banks beyond their channel. This gradually breaks down in the historical journey towards the criminalisation of states. 
- Contestation, dialogue and science have important roles in channelling power to good purposes, and away from arbitrary excess. If security services torture suspects, claiming that this saves lives, citizens must rise up to contest the arbitrary authority for police to punish. Debate is required in the legislature of the propriety of police jumping outside their authorised channels of prevention and arrest. Prosecutors should monitor the debate and charge police with assault as appropriate. If participants in a restorative justice conference credibly uncover excessively brutal use of force in an arrest, prosecutors must also act in response to that democratic contestation to rechannel police power. Good science in independent universities tests claims that torture prevents terrorism.

- Sun Yat-sen's constitutional innovation of an elected accountability and integrity branch of governance that is independent of the judiciary, legislature and executive and has impeachment authority over them is a profound contribution to republican thinking about securing freedom and preventing crime. Business regulatory institutions, particularly the central bank, must be accountable and democratised, but independently democratised from the central government. Sun Yat-sen's thought holds one clue for how to accomplish this.

- Nodal power in civil society networks has a crucial role in coordinating bridging capital among the separated powers of a democracy to tame a rogue power. Without networked governance of tyranny led from civil society, there can be no freedom. Criminalised states and criminalised markets evolve when there is no networked governance of their dominations.

- Social democratic parties that embody civic republican values of nondomination in their platforms are important to championing freedom. Yet without networked governance of tyranny from civil society, they are as vulnerable to criminalised state power as any political party. An elected pro-freedom party governing under a profreedom constitution puts freedom at risk whenever there is a failure to institutionalise distrust.

- A paradox is that societies cannot enjoy long-run freedom from anomie and violence unless civil societies enjoy destabilisation rights to restore freedom by dynamic adjustment of the constitutional order.

- Summarising so far, lessons about liberal freedom and taming ancient anomie are important to tempering domination and reducing crime, but they are not enough. Blocked legitimate opportunities must be 
opened and illegitimate opportunities closed. Institutional anomie theory insights must be realised through strong institutions of the family, welfare and education. The data further suggest that religious institutions that resist tyranny can prevent violence, that institutions of tax equity are important, as are labour market institutions and other institutions that promote equality. Particularly fundamental are separations of micro and macro powers. The promise of institutional anomie theory also requires strong business regulatory institutions, strong markets in crime-control virtue, strong civil society, strong financial, human, social, recovery and restorative capital and strong individuals. The most brilliantly institutionalised freedom could not be freedom at all if it were a freedom of timorous individuals who allowed institutions to do everything for them. At the same time, free individuals are unlikely to survive the risks of nuclear genocide and ecocide across the next century or two without a stronger United Nations.

- Uncontested commodification of too many things is a risk of American capitalism. Uncontested state control of too much is a danger of Chinese communism. Getting the balance right between market power and state power is not the right way to think about this dilemma. After all, this book shows that crime and domination are caused by excesses of state control in America and by excesses of commodification in China. The imperative is the struggle for both markets and states to be stronger in ways that temper domination in both societies.

\section{What does it mean to temper domination?}

In considering what it means to temper domination, this opening section considers abstractly the theme of this entire chapter. Next, the greater part of the chapter makes these abstractions concrete using the history of war, crime and freedom in Timor-Leste as a case study. Finally, the chapter summarises where the book has taken us so far on what we would need to measure in testing the freedom theory of what shapes empirical patterns of crime and domination.

Bad power is conceived as domination in this book. It is arbitrary power that is unchecked by a rule of law and by a plurality of separated powers. My ambition is to understand how to temper power, how to transform bad power in a society through good, tempered power. The previous chapter 
argued that the form of unequal power called domination is checked by strong markets, strong states, strong civil society and strong individuals that empower vibrant financial capital, human capital, social capital, recovery capital and restorative capital. Nondomination, according to Chapter 7, is accomplished by a complex of forms of capital that builds successful societies through enculturated trust and institutionalised distrust.

Limiting or curbing power is less appealing than tempering power, according to Martin Krygier $(2017,2019)$. Power is a good thing; it is needed to enforce legal judgements, to keep the peace, to raise funds to build schools. It is untempered power that is bad because it is arbitrary power. Power that is tempered by the discipline of the rule of law and rich separations of power is more resilient. It grows authority that is trusted by citizens as legitimate because it can be distinguished from domination (untempered, arbitrary power) (Pettit 1997). Domination destroys the trust that the previous chapter argued is the yeast for flourishing contemporary economies. For Krygier, and for ancient Greek philosophers who advanced temperance as a virtue, temperance means a 'moderating balance of elements'-for example, legal justice tempered with the compassion of restorative forms of justice by ancients who interpreted justice as shalom in the Judaeo-Christian tradition and salam in the Islamic tradition. This is also interpreted to mean peace with justice (Krygier 2017: 47). Tempered steel is made tougher, less hard and less brittle as an alloy (a balance of more resilient metals) in a test of extreme heat. For Krygier, this tempering metaphor in governance means tempered power is less brutal and less brittle. Tempered power is not weakened by the rule of law, while arbitrary power in pursuit of whims is very much constrained by the rule of law. Tempered power is more enduring as a rule of law virtue than an arbitrary 'rule of men'. ${ }^{1}$ Krygier (2019) asks why we should want law to rule; for what purpose is the rule of law a good thing? The answer he elaborates is tempering power so that arbitrary abuse of power is checked.

1 Likewise, when in common usage we temper justice with mercy, we strengthen justice. Soldiers who are tempered by combat are hardened, but also moderated through the wisdom and prudence of experience. When music is tempered, it becomes more powerful in the sense it can be modulated into other keys. Tempering a sauce in cooking means gently heating egg yolk or a dairy ingredient before adding it to improve the sauce. Usage of the concept of tempering has been in continuous decline since the late 1700s: 'Definition of "Temper", Collins Dictionary (available from: www. collinsdictionary.com/dictionary/english/temper). 
Using the example of state constitutions, Krygier quotes Stephen Holmes on the error of seeing constitutions only as a restraint on power. Constitutions are also empowering in that they enable the concentration of power for good purposes:

Limited government is, or can be, more powerful than unlimited government.

... [T] hat constraints can be enabling, which is far from being a contradiction, lies at the heart of liberal constitutionalism ... By restricting the arbitrary powers of government officials, a liberal constitution can, under the right conditions, increase the state's capacity to focus on specific problems and mobilize collective resources for common purposes. (Holmes 1995: xi)

The idea that states, markets and other institutions both temper and enable one another is an old one. Karl Polanyi (1957: 140) articulated it most influentially: 'The road to the free market was opened and kept open by an enormous increase in continuous, centrally organized and controlled interventionism.' Half a century before Polanyi, Max Weber (2002) made the point that capitalism could neither take off in a dominating way nor flourish in a good way without a strong state bureaucracy. Peter Evans (1995) advanced on Weber and Polanyi in a way that resonates with the Timor-Leste case study in this chapter. Evans was worried about states that take a trajectory towards becoming predatory states, as in his example of Zaire, which became Democratic Republic of Congo. This was contrasted with societies like South Korea that lifted themselves above poverty and corruption through becoming developmental states.

As in the example of South Korea, to become a free and flourishing society, a strong state is needed that can be a 'midwife' to development. That state requires an autonomous professional bureaucracy that is competent and meritocratic. Long-term careers of dedication to public service are vocations that are valued. In addition, for Evans, it is essential that the state has embedded autonomy. It is the embeddedness of bureaucratic autonomy that prevents states from becoming predatory. Embeddedness is a key to tempering the power of bureaucrats from pursuing their own interests rather than public goals. For Evans, bureaucracies must not be insulated from civil society in the way they are in the Weberian vision of bureaucracy. They must be autonomous, but the autonomy must be embedded in 'a concrete set of social ties that binds the state to society and provides institutionalized channels for the continual negotiation and 
re-negotiation of goals and policies' (Evans 1995: 12). The apparently contradictory tempered alloy of state autonomy, strength and coherence, on the one hand, and embeddedness on the other, is, for Evans, the underlying structural condition for becoming a developmental state like South Korea rather than a predatory state like Congo. This is also present in this book's discussion of Peake and Forsyth's (forthcoming) relational state and in its diagnosis of the networked governance of freedom and predation in Timor. Relational embeddedness is key to the paradox of separated powers that have enough autonomy to exercise strong state power in a way that advances freedom and controls crime, while experiencing enough tempering of that power to prevent separated power from becoming a criminalised state or a criminalised bit of a state.

One reason that plural checks are the heartland of meaningful embedded autonomy that tempers power is that concentrations of power are so variegated and nimble in the conditions of contemporary capitalism. Without a networked governance of tyranny, without the embedded autonomy of a strong state, strong markets and strong civil society, countries like Congo will continue to suffer high rates of poverty, violence, theft and rape and the predations of a criminalised state that enables criminalised markets and criminalised crony networks that crush freedom.

The tempering approach to power grows from an understanding that there is no such thing as an all-powerful state, institution, corporation or person. The most powerful states-the United States, China, the United Kingdom, Germany and Japan — have all had historical moments when they have unravelled into anomie and devastation and will have them again in the future. The most balanced, powerful individuals experience depression, rage, hate, terror, gluttony, sloth and self-harm. The greatest universities lose their way into intellectual irrelevance and become seedbeds of relevance to evil. German universities did this when they were seedbeds of Nazi youth in the 1920s and 1930s and AngloAmerican universities did this when they built the instruments of nuclear and biological warfare. Few of the greatest corporations in history survive more than a century before they crash, failing to rise again. No orchestra stays great for long if it fails to be attuned to feedback from audiences and conductors. They require a spirit of innovation that grows excellence with well-tempered claviers, conductors and critics. 


\section{How power was tempered in Timor-Leste}

To make Krygier's abstractions practical, consider my attempt with Hilary Charlesworth and Adérito Soares in Networked Governance of Freedom and Tyranny (Braithwaite et al. 2012). In Indonesia, East Timorese student leadership was critical to the people-power movement on the streets of Jakarta that helped democratise the country and overthrow the cronycapitalist regime of President Suharto in 1998. This involved 270 million people in as genuine a transition to democracy as the world saw in the past 30 years. In the process, East Timorese people power won democracy for an independent Timor-Leste in 1999. Braithwaite et al. (2012) is about how that was accomplished by networked governance, after the fulcrum of struggle shifted from armed struggle to nonviolent civil society struggle. This nonviolence accomplished regime change at the commanding heights of an exceptionally dominating state (rather as in South Africa's transition from Apartheid). The transition was punctuated by moments of extreme authoritarianism and violence, especially in 2006 when UN peacekeeping was forced to return to Timor.

Acemoglu and Robinson (2019) point out that the first deep transitions to republicanism in the wealthiest region of Europe with the highest concentration of large cities between 1000 and 1300 CE, in Northern Italy, were also rocky in this way. Most Northern Italian republics at some time negotiated their conflicts by appointing podestàs (magistrates) from outside the republic who would be fully independent of the ruling families and factions. They often arrived with a formidable transitional administration. For example, one arrived in Siena in 1295 for a year with a staff of seven judges, three knights, two notaries, six squires and 60 police from his own province (Acemoglu and Robinson 2019: 148).

The problem in Timor-Leste was that once the new leadership group consolidated sovereignty over a newly independent country after the 1999 UN referendum, the leaders wilfully cut themselves off from the networks of marginalised people in civil society who had helped them humble power in Jakarta. This was rather like what happened with the consolidation of sovereignty into the hands of African National Congress leaders post Mandela. Our book displays how the weapons of the weak in civil society were mobilised a second time to temper the power of their president and prime minister and rebuild a distinctive and variegated hybrid of separated powers in a democratic Timor-Leste today. Like Krygier in his 
work on contemporary Eastern Europe (Krygier and Czarnota 2006; Krygier 1996), Braithwaite et al. (2012) focused on the concern that the forces organised against domination could become sources of domination from the moment they assumed sovereignty over a state.

We interpreted the problem with the Timor-Leste transition as being that it was not republican enough. Until 2006, transitional governance failed to keep working at institutionalising tempered power in the country. Yet, when their leaders directed arbitrary power back at civil society, especially at the Catholic Church, civil society remobilised and re-established a richer democracy with tempered power after 2006. That book's title, Networked Governance of Freedom and Tyranny, signifies that networks can restrain the excesses of realist international diplomacy and check the excesses of executive domination within a state to deliver republican freedom. Networked governance was defined as the action of plural actors linked by coordinating dialogue. Relational dialogue encompasses both interdependence and sufficient autonomy for different nodes of the network to check and balance other nodes of (tempered) power. Networks can only govern themselves in a nodal way (Shearing and Wood 2003; Drahos 2004; Burris et al. 2005). Inherent in that proposition is the claim that even sincere democrats who seize nodal control are at risk of corrupting the separation of powers to preserve their hard-won victories. While networked governance has a more variegated horizontal architecture than state governance (Castells 1996; Sørensen and Torfing 2016), networks of capacity and accountability can be linked to every level of multilevel governance. This includes every layer of subnational, national and international hierarchies. Sometimes they are coordinated by state regulation, and sometimes not.

Networked accountabilities that temper power enable regimes to change in ways that prevent one form of enslavement from replacing another. Domination can be continuously challenged by networks that renew themselves with novel ways of checking power that are not confined to enduring constitutional balances. Variegation in checks and balances is our theme here. I join others like Jamie Peck (2013; Peck and Theodore 2007; Jessop 2015; Zhang and Peck 2016) in valuing an understanding of variegated capitalism. As concluded in the previous chapter, the politics of how to temper power in such a world must involve variegated separations of powers. One of the more exotic variegations directly witnessed in the traditionalist, predominantly rural village society of Timor-Leste in 2006 was the ritual ripping out of the heart of a terrified pig in the presence 
of dead ancestors angered by the capricious exercise of power by the country's cabal of leaders. I had a ringside seat-unfortunately, next to the pig. There were genuine tears from these party hardmen that their people had found it necessary to humble their power under the wiser eyes of the ancestors in this way. As a result, these leaders genuinely did re-empower the institutions of traditional civil society presided over by the ancestors, as well as the church, opposition political parties and, to some degree, the courts and the constitution, at least for a period after 2006. Somehow, I fear that invocation of appalled ancestors might not have worked in Donald Trump's America. Nor would accountability to a UN transitional administration, which played an important part in preventing the resurgence of various dominations in Timor-Leste, especially war. For variegation to work, it must be responsively attuned to local meaning-making.

Previous chapters posited it as definitional of institutions that temper power and prevent anomie that they must have a degree of stability. They must also be able to adapt dynamically, however, repairing the ship of republican society at sea while keeping it afloat. Roberto Unger (1983, 1987) introduced the notion of 'destabilisation rights' as a way of thinking about this dilemma. Given that rights reside with the citizens of a republic, destabilisation is more likely to productively keep the ship afloat when it comes from the people, rather than from institutions such as the military, a political elite or an interfering foreign power. Charles Sabel and William Simon (2004) further developed the concept of destabilisation rights within the American pragmatist tradition of 'democratic experimentalism'. These are rights to unsettle and open up state institutions that persistently fail to fulfil their functions. Destabilisation rights are dynamic checks on failures of institutionalised accountabilities to do their job. For example, the right to private litigation can combine with street demonstrations to destabilise defunct structures of environmental regulation (Boyer and Meidinger 1985). Oppressed minorities can appeal for rights redress to UN institutions. Destabilisation rights enable a politics of dis-entrenchment. Networks can deliver experimental innovation by reinvigorating the separation of powers. The state is often dug too deep into ancient entrenchments for innovation and democratic experimentalism. Western doctrine on the separation of powers has stultified because it has not been open to learning from the democratic experimentalism in civil separations of powers revealed in non-western histories such as that of Timor-Leste. 
The past three chapters showed that free republics with low crime must radically pluralise their vision of how to separate and temper powers within the state so the state has pluralised branches of separated powers rather than just the traditional three (legislature, judiciary and executive). How can we enliven a political imperative for separations of powers that progressively become more separated? The history of Timor-Leste can be read as one of progressive struggle for continuous improvement in securing ever more separated powers; not just for Montesquieu's (1977) tripartite separation of powers among an executive, legislature and judiciary, but also for much more variegated and indigenously attuned separations of ever more powers; not just separations of government powers, but division of both private and public powers. Braithwaite et al. (2012) documented dozens of separated powers in response to Timor-Leste's post-conflict dominations. Capitalism is a continuous process of creatively destroying old concentrations of power and constituting even more worrying ones. Hence, the struggle for freedom must be more than a struggle for a new democratic constitution that guarantees a conclusive separation of powers. It must be contestation of an evanescent constitutionalism that struggles to continuously deepen separations of powers at every stage of a nation's history.

A republic is an unfinished struggle towards a polity in which each separated power has sufficient clout to exercise its own functions with support from other separated powers. This is not a new perspective. Hannah Arendt (1963: 300) quoted Benjamin Rush complaining in 1787 of those who confuse the struggles of the

American revolution with those of the late American war. The American war is over; but this is far from being the case with the American revolution. On the contrary, nothing but the first act of the great drama is closed.

A republic is a polity in which no one centre of power is so dominant that it can crush any other separated power without the other separated powers mobilising to push back that domination. The Timor-Leste case study showed that Holmes and Krygier are right about the imperative to have a positively empowering vision of the constitution:

Republicanism does not require powers that are so diffused that separated powers cannot act decisively. The executive is empowered to declare war, the judge to declare guilt, the legislature to declare laws. Decisiveness for the judge is actually enhanced by the 
knowledge that only an appellate court can overturn her decision on an error of law; she cannot be dominated by a prime minister who demands the acquittal of a political crony. Decisiveness for a constable on the street is knowing that she is the one with the power to decide whether to arrest a judge who appears to assault his wife; then it is no longer in her hands but in the hands of the separated powers of a prosecutor. Decisiveness for a general is knowing that once the executive declares war, she can conduct it in accordance with laws of war approved by the legislature, without interference from politicians who think of themselves as armchair generals.

Of course, a mature constitutional debate is needed to fine tune separated powers to ensure that each can decisively perform its function without domination from any centralising power and without confusion as to who exercises each separated power, and under what norms. None of this is to deny that democracies must at times debate trade-offs between greater accountability and greater efficiency. Separated powers of civil society and the media to speak assertively during those constitutional debates are critical elements of separated powers that get the separations clear and effective. (Braithwaite et al. 2012: 128-29)

When the separations are clear and effective, yet dynamically responsive to changing societal and global circumstances, they have a claim on the respect of citizens. This respect is a bulwark against the anomie and violence that characterised Indonesian society in the late 1990s (Braithwaite et al. 2010a). It is the antithesis of legal cynicism (Sampson and Bartusch 1998). Dynamism is a neglected topic in debates on the separation of powers. One of the things republican revolutions have done throughout history is dis-entrench powers. Destabilisation rights and 'democratic experimentalism' (Dorf and Sabel 1998) unsettle and open up state institutions that persistently fail to fulfil their functions. Networks are imperative for experimental innovation in the invigoration of separations of powers because of states' propensities to rigidify.

One risk of richly separated powers is that they can induce gridlock. Networked separations of powers are themselves the best ways of tempering the inefficiency of gridlock. The empirically grounded conclusion of Peacebuilding Compared's Timor-Leste and Indonesia books was about embedded autonomy (Evans 1995): 
For most tasks of modern governance, networks get things done better than hierarchies. Well-designed networks of power are not only mutually checking upon bad uses of power; they are also mutually enabling of good capacities for power. Networks must be coordinated and sometimes-not always - the state is the best candidate to supply a key node of coordination. For most problems, strengthening state hierarchy to solve problems is not as effective as strengthening checks and balances on hierarchy as we also strengthen private-public partnerships, professions with technocratic expertise on that problem, civil society engagement and vigilance, and other networks of governance, while at the same time strengthening coordination of networked governance. The most effective governance is rarely centrally monopolised; it is usually messily attentive to multiple accountabilities. This is not to deny that there must be agreement on who will make the final call on matters that have not reached resolution after deep contestation under a separation of powers. Elections are one such state institution with this usefully ultimate capacity to break a logjam (without violence). So are state courts. On legal matters, as valuable as it is to have a rich tapestry of legal pluralism where the national rugby judiciary regulates most violence on rugby fields, it is also valuable to have state appellate courts that have the legitimacy to make ultimate decisions on the basis of a synoptic view of all the adjudication that has occurred across that tapestry ... Gridlock is a risk of separated powers. Often it is more important that things are settled than settled right. Paralysis and disengagement in the face of great problems are profound risks, not only in times of war. Executive government has an oversight responsibility for ensuring that really big problems do not fall between the cracks. This is not the same as saying the government should fix them. It is to say that the state has a responsibility to take a synoptic view of a society, and to catalyse action when lesser actors are paralysed by the enormity of the challenge. We see this need most acutely at times of great natural disasters when so many leaders of civil society are busy bailing out their house or looking for lost families. One of the great examples of a chief executive with synoptic vision in the twentieth century was China's Deng Xiaoping when he saw in 1978 that the institutions of state production were bogged down. He opened up the Chinese economy to private institutions that broke through many of the production bottlenecks and bureaucratic gridlocks that were grinding the economy to a halt. We might even say that the most important role of state political leaders is to be gridlock breakers: to get that budget through the legislative contestation process, 
to issue an ultimatum to an enemy state of a kind that has less meaning when only a general issues it. Yet the ultimate power to break gridlock resides with the people when they take to the streets in a revolutionary moment in which they persuade the media or the military to side with the revolution. Republicans hope these will be revolutionary moments that dis-entrench bad power and entrench new separations of powers that secure freedom from domination. (Braithwaite et al. 2012: 303-4)

In the short term, there is little guarantee of that. Chapter 11 grapples with the problem that transitions from the untempered power of communism or Apartheid to a more tempered constitutional order are inherently anomic during the transition. These moments of transition to tempered democracy can indeed be exceptional periods when elevated crime or war is the price of freedom, as opposed to something freedom's institutions can conquer in the longue durée. In that longue durée, we must be deeply suspicious of arguments that a dictator can get the trains to run on time or can increase economic efficiency by overruling a court or a regulator that needlessly slows investment that would benefit the people:

The experience of history ... is that autocrats more often exercise their domination for corrupt and patrimonial purposes that reduce the efficiency of national resource allocation. So in the long run many separations of powers that seem inefficient to the politically naive are in practice economically efficient.

Part of the efficiency dividend from separations of powers that are attuned to local realities is from a more efficient division of labour. Because central bank board members focus their intelligence and training on the large and intricate challenge of securing monetary balance for an economy, they are likely to make better decisions of this specialist kind than are the generalist politicians of the cabinet. Because police training is in community policing that enrols the community to do most of the serious business of crime control, they become better at it than the military with their training and experience in the use of maximum force. Our Timor-Leste narrative has well illustrated the provocation and inefficiency that can arise when the military takes over public order policing. (Braithwaite et al. 2012: 300)

The most inspiring thing about the struggle that led Timor-Leste to become a free, low-crime society was that its political strategy was for Timorese students in Jakarta to be shock troops who made the most creative sacrifices for the democracy movement on the streets. Their 
courage caused Suharto to fall at the moment of economic crisis. Powerless students of tiny East Timor were fulcrums when this profound democratic transformation was levered in the world's fourth-largest country. A gift of networked governance of freedom and tyranny from the students of Timor-Leste to the people of Indonesia was the strategy that worked for ending the Indonesian military occupation of Timor-Leste.

\section{Greening New Deal social democracy}

Productive innovation is always ahead of redistributive innovationthrough the tax system, for example-in untempered capitalism. Markets in vice are one step ahead of regulatory institutions. Regulatory institutions cannot respond to vices that markets have yet to invent, so they play catch-up, though B-grade economies can prepare themselves for the next wave of market abuse by watching closely the waves of abuse crashing over A-grade economies today (Braithwaite 2005b). Chapter 2 showed that derivatives markets come in forms that are markets in virtue and other forms that are markets in vice. In both their good and their bad versions, these markets have accumulated staggering wealth in the hands of the super-rich, who are cocooned in financially engineered shelters from obligations to pay their share of tax. This profoundly eroded the legacy of the New Deal in America. Large corporations that pay no tax have at the same time been beneficiaries of profligate corporate welfare in the form of subsidies, research and development grants, socialist bailouts of capitalism's losses, and the like. The US state has ceased being an institution to redistribute wealth from the super-rich to the rest of society through its tax and welfare systems in the way it did from the New Deal until the 1960s. Today, it redistributes wealth from the rest of society to the super-rich (Braithwaite 2005b).

This means that the old-fashioned social democratic politics that gave birth to the New Deal is as relevant today as ever. Versions of republicanism that see it as being about political equality as an ideal, but not economic equality (for example, Sunstein 1988), therefore do not have much more appeal than liberalism. Philosophers' debates about what level of inequality is or is not morally acceptable are unimportant in the context of a social system called capitalism that always drives already unacceptable levels of inequality to ever higher levels unless checked by redistributive politics. In the history of capitalism, no society has accomplished a level 
of redistribution that has triggered even the beginnings of a debate among social democrats that perhaps this was too much equality. Too much equality is something that might happen in some philosophically possible world, but never in any sociologically existing capitalist world. We can say the same about equality between men and women, rich and poor countries or people with and without disabilities.

If freedom as nondomination is your ideal, poverty and structured disadvantage make freedom impossible. Choices for the poor are dominated and constrained by those with the economic power to push them around (Pettit 1997, 2014). As social democrats play catch-up with the latest power plays, the financial engineering to escape obligations to the poor, the stock market fiddling, the tax shelters and the monopolisation of the intellectual commons, social democrats need not worry about being too successful in any future sociologically possible world. Indeed, social democrats will not be very successful at all if they are old-style New Dealers infatuated only with the politics of the welfare state. The statist politics of provider capitalism is insufficient to deliver social democratic objectives. Markets are too innovative in new vices, too internationally footloose, for statist regulation/redistribution to be capable of saving civic republican ideals. Nor can nondomination be effectively pursued through a single social democratic party or a single set of NGOs such as the trade union movement. Nondomination requires social democrats to be networked with the women's movement, human rights NGOs, green NGOs, indigenous rights groups, development NGOs and the National Citizens' Coalition for Nursing Home Reform (Chapter 6). That is one difference between the New Deal and a Green New Deal.

If it sounds like a politics of infinite complexity, we should remember the pragmatics of the nodal governance tradition (Burris et al. 2005). Because a networked society is more fluid, complex and indeterminate than older structures of government such as parties and ministries, understanding how governance unfolds is more challenging. This challenge has increased the appeal of nodal governance as a way of thinking about the possibilities for strategic regulatory action. The question becomes what are the nodes where networks can be organised, where the levers at the disposal of one network can be tied into the levers available to another or several networks? A node is a place where resources, ideas, deliberative capability and leadership are available to make networked governance buzz. These nodes are the focus of attention in this theoretical tradition because a synoptic 
understanding of how whole networks and sets of networks operate is beyond our grasp. What we may be able to grasp is whether there are effects when nodal governance is mobilised to bind networks together.

This is an old idea in Eastern philosophy. Sima Qian around 89 BCE quotes the following exchange with Confucius: 'Do you think me a learned, well-read man?' 'Certainly,' replied Zi-gong. 'Aren't you?' 'Not at all,' said Confucius. 'I have simply grasped one thread which links up the rest' (quoted in Castells 1996: 1). Each strand of a web of controls that seeks to govern some person or some phenomenon may be weak, and we may have a dim understanding of this complex web of governance. Yet, if we learn to pull the right strand at the right time, we might find that the entire fabric of the web of forces for liberation tightens to become quite strong. Conversely, we can learn that if we pull the wrong strand at the wrong time, the entire fabric can unravel. From a republican point of view, we should be interested in how to cause the unravelling of webs of control that dominate citizens in an arbitrary way, and how to secure webs of control that prevent domination. This can be accomplished by strategic deliberation at strategic nodes of networked governance.

A richly tempered republic gives us frequent opportunities to vote for people who represent our interests, plus many nodes of governance that give us opportunities to contest power and deliberate in our own voice at that node of governance. Tempering domination does not require that we all spend our evenings in meetings, just that enough of us assume responsibilities to temper power when we see injustices not being righted. It requires a learning democracy where enough of us learn to care to engage and learn to be democratic through early experiences of deliberation in schools, families and restorative justice conferences. In addition, citizens must learn how to convene nodes of governance at the strategic intersections of networks that can regulate abuse. Put another way, through these means, we learn the collective efficacy that prevents crime and defends freedom.

Manuel Castells (1996) was right in his networked governance insight that, while states still matter greatly, governance is becoming less statist and more networked across the spectrum of all public issues. If this is so, deliberative opportunities for nodal governance become increasingly central to the institutions of republican governance. Restorative justice is an example (as discussed further in Chapter 9). A combination of the nodal governance of networks from below and meta-governance 
of networks by institutions of representative democracy can provide superior accountability and superior transparency than either approach alone. The superiority comes from covering the weaknesses of hierarchical accountability with the strengths of horizontal accountability and vice versa. A republic nurtures a creative tension among electoral accountability, accountability to the rule of law, contestable accountability enabled by separations of powers and directly deliberative accountability of each to every other in circles of denizens. Accountability is accomplished by widening circles of deliberative accountability (for details, see Braithwaite 2006a). This bubbles up the justice of the people into the justice of the state. Meanwhile, the state takes responsibility for educating its citizens in a rights culture that filters the justice of the law down to the justice of the people. All nodes of separated private, public or hybrid governance need enough autonomy so they cannot be dominated by other nodes of governance. Equally, each needs enough capacity to check the abuse of power by other nodes so that a multiplicity of separated powers can network to check any node of power from dominating all the others.

When our vision of democracy is messy-and is of deliberative circles of accountability - there are many kinds of circles we can join that we believe actually matter in building democracy. Democracy is, then, not something we lobby for as a distant utopia when the tyrant is replaced with free elections; democracy is something we start building as soon as we join the NGO, when we practice responsively as a lawyer, establish business self-regulatory responses to demands from green groups, deliberate about working conditions with our employees and employers, educate our children to be democratic citizens or participate in politically serious global intercultural conversations on the internet. If, on the other hand, we believe only in the hierarchical model of accountability in Figure 6.1, and if we apply it to an institution like a police department, we discover eventually that a police department is like a fish that rots from the head down. Who guards the guardians? If our only solution to corruption by an $n$ th-order guardian is an $n+1$ th-order guardian, we can be saved the trouble of corrupting many and concentrate just on corrupting the $n+1$ th guardian. That is why the jury is a good anticorruption institution; it is harder to corrupt 12 different citizens in dialogue around a table than it is to bribe a judge. The republican vision of accountability for a lowcrime society is of circles of accountabilities that check hierarchies of accountability so that everyone is accountable to everyone else. 


\section{Constitutional meta-governance for freedom and against the criminalisation of societies}

This section shifts focus to the role of constitutional law in tempering domination and enabling multiplicities of accountabilities to flourish in a society. Constitutional law may be more important than criminal law to the prevention of crime. Republican constitutional law can help enculturate trust and institutionalise distrust. With this challenge, there is much to learn from ancient Chinese wisdom from before the invention of criminal law institutions, and even more to learn from the republican thinking of Sun Yat-sen a century ago.

One ancient Chinese safeguard against the criminalisation of the state was the institution of an independent examinations branch of governance. To be appointed as a civil servant, prosecutor or judge, citizens had to pass an exacting examination tailored to the professional demands of the examinations branch. The branch served as an ancient Chinese method of constitutionally regulating bad governance and fostering competence. The idea of independent branches that could regulate the executive government was also evident in the office of the censor (御史; $y \dot{u} s h i$ ) under the Qin and Han dynasties, which influenced the modern constitutional thinking of Sun Yat-sen (Braithwaite 2016b). Later, the Sui and Tang dynasties established the office of the tái (臺), which supervised the conduct of civil servants and military officers.

In Sun Yat-sen's Republic of China Constitution that was voted for in 1928, but not implemented until 1947, this tradition was picked up in an innovative adaptation of western republican thought to regulate the anarchic conflicts for power in the early Chinese republic (Tung 1964). Two years after Sun Yat-sen's constitutional ideas came into force in China, the republic was swept away by Mao's communists. Chiang Kai-shek's civil war government ultimately fled to Taiwan with an authoritarian vision of how to implement this constitution.

Sun Yat-sen's constitution provided for five independent branches of government: a legislature, an executive, a judiciary, an examinations branch and an accountability and integrity branch called the Control Yuan. The Control Yuan was elected until a 1992 revision to the Constitution. Clause 90 of the 1947 Constitution defined it as the 
highest supervisory organ of the state'. Fundamental to thinking about the Control Yuan was that it would check the capture and abuse of power in regulatory agencies in the executive branch, but also in the legislature and judiciary. Instead of allowing these branches to impeach their own wayward members-something Sun Yat-sen rightly saw as a woeful weakness of western constitutions - the accountability and integrity branch would independently adjudge impeachment. The constitutional realities of the 1947 Constitution have meant that censure and 'corrective measures' are speedier and more potent than impeachment (Ma 1963). In the 30 years following the demise of martial law in Taiwan, there were only 541 impeachment cases (Caldwell 2017: 757). Sun Yat-sen's original thinking on the separation of powers had a sixth branch, the Auditing Yuan. In 1931, the Auditing Yuan was subsumed as the Ministry of Audit into the Control Yuan.

Contemporary reinvigorations of this Chinese republican thought could be considered for the next constitutional revolution that occurs in a western democracy. This is particularly so for the contemporary West where financialisation has captured politics and the regulation of capital in a way that is dangerous to the sustainability of freedom (Braithwaite 2019). The job of an independent regulation and accountability branch is the regulation of the state, meta-governance (the governance of governance) (Sørensen 2006) or meta-regulation (Parker 2002; Morgan 2003; Grabosky 2017). Consider the meta-regulation of central banks. Here, the thinking of Steven Klein (2020) is helpful. Klein concedes that central banks must be independent of elected governments. Independence helps avert an electoral cycle of monetary policy that excessively promotes inflation by priming the pump in election years. The other side of that policy folly is being dangerously contractionary to restore balance in the year after an election.

Yet for Klein, central bank independence has led to insufficient responsiveness in democracies overly governed by key performance indicators like inflation targets, which work well enough when markets are functioning well but work badly during those large proportions of time when markets are in crisis (Quiggin 2019). We saw clearly with the 2008 Global Financial Crisis and the 2020 Covid crisis that central banks must be key players in doing deals with big banks and other corporations to save them from collapse. Without being democratically accountable, while hiding behind a fiction of political independence, they sit down with presidents and prime ministers to decide, no, we will not bail out 
Lehmann Brothers; yes, we will bail out Citigroup and Bank of America. Most importantly, according to Steven Klein, they decide to allow millions of impoverished mortgage holders to crash and burn. Central bankers in the United States come from Wall Street and return to Wall Street, which is why they see their accountability pressure as coming from Wall Street, not Main Street. So, Klein says, central banks must be democratised, but independently from the executive government. This, according to Klein, is the way to escape a dangerous trilemma of independence, versus crisis prevention, versus domination. The trilemma is, first, independence from democratic politics and from the electoral monetary cycle; second, dependence on the economic cycle that means a political imperative to save the society by priming the pumps during crises; and third, tendencies to enact those imperatives in ways that serve those who dominate and disserve the dominated.

An independent accountability and integrity branch like the Control Yuan that is elected for only one term is one possible pathway to an independently democratised governance of money and central banking. Otherwise, central banking is a system of domination that guarantees the value of the currency by promising to take money in demands for future taxation of citizens, without being accountable to those citizens who underwrite their decisions. Otherwise, central banks continue to drive a redistributive politics of dismantling welfare with a 'debt-fare' of predatory lending to the poor, an economics of debt and the financialisation of capitalism (Braithwaite 2019). Credit 'transforms money into power' (Klein 2020: 31). For Klein, and for me, an elected accountability branch of governance to meta-regulate central banks would hardly be enough. A vibrant civil society politics of agonistic contestation of financialisation is additionally imperative through social movements like Occupy Wall Street this century and the organised consumer movement inspired by Ralph Nader and many Progressive Era muckrakers during the previous century (Chapter 12). Klein (2020: 19) describes this as the imperative for Polanyian 'social freedom through democratic self-organization and collective struggle in the economy'.

Sun Yat-sen's five branches of governance persist in the Taiwanese (Republic of China) Constitution today. ${ }^{2}$ During Chiang Kai-shek's long rule of militarised authoritarianism, Sun Yat-sen's ideals were gutted.

2 Office of the President of the Republic of China, Constitution of the Republic of China (Taiwan), Chs V-IX (2005) (available from: english.president.gov.tw/Page/94). 
The Control Yuan became a puppet of executive rule even as Taiwan turned back to democracy. While calls to weaken or abolish the Control Yuan are incessant, in recent democratic renewals of Taiwan, the Control Yuan has done some useful meta-regulatory work, such as implementing the Sunshine Acts to ensure transparency, regulating political donations and maintaining registers of assets held by public officials. ${ }^{3}$ In addition to supervising what would be called the auditor-general function in the West, the Taiwanese Control Yuan has supervised the integrity and independence of the other four branches by way of the Control Yuan Committee on Anti-Corruption.

Other committees exist for other purposes. There is a Control Yuan Committee on Human Rights with functions similar to western human rights commissions. There is a Standing Committee on Judicial Affairs and Prison Administration, performing the functions of judicial self-regulation in the West as well as prison ombudsman and prison inspectorate functions. The Control Yuan also has an oversight Standing Committee for National Defence and Intelligence Affairs, as well as a committee with oversight of procurement by all branches of governance. A separate standing committee advocates for, checks and balances ethnic minority affairs. Although the Control Yuan, as in white-settler societies, has a class interest in upholding Han Chinese interests over those of the indigenous owners whose land was stolen from them, it does seem a visionary idea to have a sub-branch of governance with the job of holding the other branches to account on questions of First Nations rights and reconciliation-more so one that has a high proportion of indigenous staff and that is independent of the judiciary. An accountability branch might consider a new treaty with indigenous peoples that overturns doctrines of terra nullius long enforced by courts that have defended the land rights of the occupiers, including those of wealthy judges. Institutionalised independence from a legislature, judiciary and executive with histories of rejecting indigenous self-determination could be a way to open doors to a form of self-determination that delivers a more radical vision of indigenous collective efficacy: Connectedness, Hope, Identity, Meaning and Empowerment for first nations.

3 For a survey of the history of the Control Yuan and its changing powers, see Ernest Caldwell (2017). 
The Control Yuan has been under threat not only from the authoritarianism of pre-democratic Taiwan and from ceasing to be an elected branch since 1992. The policy of the current Democratic Progressive Party government had been to abolish the Control Yuan and move to a more conventional tripartite liberal separation of powers. In 2020, it pulled back from this to repurpose the Control Yuan as a national Human Rights Commission. The chair of the Control Yuan as of 2020 is a former member of the Democratic Progressive Party, which is a slap in the face to Sun Yat-sen's view that the impeachment of political leaders and judges should be independent and totally removed from the hands of political partisans. Bills were being debated in the legislature during 2020, however, to return to strengthening the guarantees of political independence. For the most part, we could summarise by saying that Sun Yat-sen's vision for the Control Yuan has been overwhelmingly discarded by the two major-party machines. These machines see it as an encroachment on their power that they would rather do without.

Thailand is the only country to have emulated Taiwan's constitutional architecture of an accountability and integrity branch. The 1997 'People's Constitution' was a radical document in terms of public participation and rights accountability. It was dismantled by the 2006 military coup and the 2007 Constitution promulgated by the Council for National Security, which made it a crime to criticise the draft constitution (Sapsomboon and Khundee 2007). As I completed early drafts of this chapter in December 2020, student-led demonstrators were massing again on the streets of Thai cities with demands for a new people's republican constitution. Covid-19 then began to dampen this politics of the street. It is perhaps testimony to the virtues of this architecture that tyrants found it so dangerous and students found it worthy of endangering their lives to revive. Members of the fourth inspection branch of the 1997 Thai Constitution oversaw impeachment in the other three branches, the election commission, the human rights commission, the ombudsman and audit and anticorruption functions, as in Taiwan's Control Yuan. The 1997 Thai Constitution involved the further innovation that membership of this fourth branch was limited to candidates who were not members of political parties and were for one term only. This served as a prudent check against progressive capture by parties and business cronies that dominate the executive and legislature and stack the judiciary. 
Business regulators such as competition authorities, food and drug administrations, securities regulators and banking regulators must be independent. This has proved an impossible ideal under crony-capitalist regimes. It is an ideal constantly white-anted under liberal capitalism by business leaders who make fat political campaign contributions. During the 10 years I was a part-time commissioner with Australia's most independent, credible and respected business regulatory agency-its competition, consumer protection and product safety authority-we nevertheless had a day when it was alleged on the front pages of the newspapers that our chair had taken a call from his minister, the Attorney-General, that had influenced our decision on the biggest merger in the country's history. Our chair issued an indignant press release saying that the commission was an independent authority that was not subject to political influence over merger approvals and that he had had no conversation with the AttorneyGeneral about the matter. That was true; he had not taken the alleged call from the Attorney-General, but he had taken one from the Prime Minister on the merger and I had spoken to the Prime Minister about it myself. Hence, independent meta-governance of independence and integrity is imperative even for the most independent of regulators. What would be desirable is for all major independent business regulators to have a dottedline reporting relationship with the executive government and a solid-line accountability relationship with an accountability and integrity branch like the Control Yuan. That fourth branch would be responsible for the meta-governance of all business regulation. It would impeach regulatory commissioners when they allowed their independence to be politically compromised by political donors.

There is something attractive about Sun Yat-sen's architecture of a fourth accountability branch of governance comprising many sub-branches. This is especially so for the challenges that white-settler constitutions have so badly mishandled, such as theft of land from indigenous custodians and righting the dominations of genocidal frontier wars to ethnically cleanse indigenous landowners. For societies in which settlers have forced indigenous landowners off their country, there is that special appeal in one of those branches being elected from indigenous peoples for oversight of the other branches in terms of the longue durée of reconciliation and treaty renegotiation. This has appeal in the context of histories of indigenous dispossession, mass atrocities, disproportionate contemporary imprisonment and all other indigenous rights abuses. Constitutionally empowering this kind of compassionate entrenchment of first nations 
regulatory authority is appealing and novel. ${ }^{4}$ For societies ruled by bankers' power (Braithwaite 2019), the idea of independent meta-regulation of banking regulators, central banks and labour regulators to ensure they are not captured by capital or by politicians on the prowl for campaign contributions is an attractive one to pull from the top drawer of activists' constitutional reforms after the next crisis.

\section{Summarising powers to be strengthened and separated to temper domination}

What follows is a kind of summary of the theoretical induction of the past eight chapters about anomie and domination and their relationships to crime and freedom. Because the theoretical journey has involved considerable embrace of ancient anomie, then Merton, Cloward and Ohlin and, finally, Messner and Rosenfeld's synthesis of institutional anomie theory, we start by building on the now considerable evidence that supports their theoretical conclusions-first, with ancient anomie, then with institutions of family, welfare and education. The polity came in for special elaboration because it had too thin a treatment in Messner and Rosenfeld. In considering how we explore a theory of crime and freedom empirically, the aim is to test whether its key variables explain not only homicide, robbery and burglary, but also levels of corruption, tax compliance, banking crime and environmental stewardship. Unfortunately, criminologists are comparatively good at measuring crimes like homicide and incapable of measuring corporate crime with reliability and validity. When we try, we tend to allow the less serious to dominate the variance in the measure. This drives out the influence of the more important dimensions of the criminality of the powerful. That is not an argument against trying to get better at it.

The conclusion to Chapter 2 has already summarised how a crossnational test of the following hypotheses could be modelled in a stepwise quantitative analysis. Readers uninterested in testing criminological theory quantitatively may decide to skip quickly to the conclusion of this chapter.

4 It is also consistent with the proposals in the Uluru Statement from the Heart, which came about after a dialogue among Australian Indigenous leaders in 2017 (2017 First Nations National Constitutional Convention, Uluru Statement from the Heart, 26 May 2017, available from: www. referendumcouncil.org.au/sites/default/files/2017-05/Uluru_Statement_From_The_Heart_0.PDF). 


\section{Liberal freedom}

The first hypothesis is that thin political freedom, as captured by measures such as the Political Freedom Index, predicts low crime, perhaps very weakly compared with republican freedom. This lays a liberal foundation on which to build a deeper republican freedom explanation based on a more complex view of freedom as nondomination.

\section{Ancient anomie}

Citizen commitment to the normative order can be measured adequately enough by indices such as the World Bank's rule of law indices, which Testa et al. (2017) have found to be positively associated with crossnational measures of homicide rates. Measures of legal cynicism, which are also widely associated with higher crime, are another measure of the strength of commitment to the normative order (Sampson and Bartusch 1998), though they can be as much a rationalisation as an explanation of crime (Nivette et al. 2015).

\section{Mertonian closed opportunities}

The section below on 'Labour market institutions and other institutions of inequality' outlines subsets of blocked legitimate opportunities, as seen through the theoretical lens of this book.

\section{Open illegitimate opportunities}

The indices of Cloward and Ohlin's illegitimate opportunities in cross-national comparisons include the various indicators of the size of underground economies (Schneider and Buehn 2018). A challenge of making them independent variables is that there is also appeal in using them as dependent variables that measure the extent of organisational crime. Where the channelling of funds into tax havens is high, drug empires are large, darknet trade is rife and smuggling is common, these can constitute illegitimate opportunities while they also are measures of the degree to which illegitimate opportunities are in fact being grasped. So, as researchers build models with them as measures of organisational crime, they might also create feedback loops in the model to conceive them as forms of crime that are rich in their capacity to create new opportunities 
for further crime of even more diverse kinds. The density of criminal gangs and their control of territory and markets are other measures of illegitimate opportunities.

\section{Institutions of family, welfare and education}

Messner and Rosenfeld's arguments for balancing dominations of market institutions with the countervailing strengths of institutions of the family, welfare and education have catalysed considerable evidence that these do indeed matter in preventing crime. We have seen that this literature has mobilised a rich diversity of measures of the strength of these institutions. Messner and Rosenfeld see a strong welfare state as, among other things, a fundamental support to the strength of institutions of the family that are of special importance to families with many children and one parent. There are other domains in which a strong welfare state tempers domination. This relates to mentally ill or drug-addicted persons who are totally estranged from all remnants of family, to people with a disability or the frail aged who need institutional support from the welfare state because further home care is beyond the skills and coping capacity of their family, welfare support for families who are strong and capable but who are put at risk when a financial crisis takes their home and puts them on the street or families who are strong and capable but are decimated by a deadly epidemic. There are such varied misfortunes to which the welfare state has become attuned to respond. This reinterpretation of Mertonian anomie theory means that we also interpret a strong welfare state as a fundamental bulwark against domination.

\section{Religious institutions}

Chapter 4 discussed how Messner and his co-authors launched international comparative studies suggesting that societies with strong religious institutions fare better than others in crime control. It is easy to understand why Messner and Rosenfeld did not include religious institutions in their original theory and why Messner concludes that adjustment may be needed in light of these data. In the long sweep of history in Chapter 3, we gained some insight into how religious institutions have been central to waves of anomie that destabilised whole societies and continents through war and the criminality of highwaymen and armed gangs. This refers, for example, to the devastation of the whole of Central Europe and beyond by the Thirty Years' War, in which 
wave after wave of Protestant and Catholic armies and armed gangs of predators ravaged the countryside. It refers to the cruel character of the state crimes of the Inquisition and to the genocidal religious campaigns of the Crusades and how they cascaded violence between Christians, Jews and Muslims to the present. Yet here is where theoretical adjustments that emphasise the tempering of domination come into their own. The horrors of religious cleansing in the Thirty Years' War, the Inquisition, the rise of the Caliphate and its attack by the Crusades-all arose when the most important dominations in these regions were religious, more than state or market, dominations. The globe has seen since those times a formidable tempering of religious dominations. Still, there are pockets of the planet where religious domination remains the most important domination in play. When a UN peacekeeping mission responds to a region of an African country where Boko Haram has been dominating the society, particularly its women and girls, the top priority of peacekeeping remains pacifying and tempering religious domination.

Our Peacebuilding Compared project requires more data collection for a balanced sample of armed conflicts. So far, only 67 post-Cold War armed conflicts are preliminarily coded. One telling variable is religious leaders as advocates of both nonviolence and violence at different historical moments: 'Qualitative coding of a sequence of religious leaders contributing to conflict by supporting violence, followed by religious leaders becoming advocates of peace.' Twenty-three (34 per cent) of the conflicts strongly fit this particular sequence; 18 per cent evidenced a mixed tendency towards this sequence, and just under half had no evidence of it.

Hence, in empirical evaluations of the theory of crime and freedom, the strength of religious institutions variable must be considered with historical and contextual nuance.

\section{Institutions of tax equity}

Another institution that more recent cross-national comparative work by Messner and his colleagues showed to be important was wealth redistribution through tax policy. Like the strength of the welfare state, this can be interpreted as simply another index of inequality in societies. On the other hand, there is specificity in the centrality of institutions of taxation to domination. In the history of colonialism, they have been vital to understanding armed uprisings against the British Empire, for example from India (Braithwaite and D'Costa 2018: Ch. 5) to the American 
Revolution, stirred at the Boston Tea Party. Two millennia earlier, Julius Caesar, according to George Bernard Shaw (n.d.), opined about tax and domination by empire:

Pothinius: Is it possible that Caesar, the conqueror of the world, has time to occupy himself with such a trifle as our taxes?

Caesar: My friend, taxes are the chief business of a conqueror of the world.

Taxes on capital, wealth and real estate are particularly important to increased equality because the International Monetary Fund (IMF) has concluded that 'income Ginis, on average, are half the size of wealth Ginis' (Dabla-Norris et al. 2015: 16). This relates to Piketty's (2014) structural insight that inequality is driven up by returns to capital that are higher than overall economic growth $(r>g$, where $r$ is the rate of return on capital and $g$ is the growth rate of the economy).

In crony-capitalist societies, it continues to be the case that what Acemoglu and Robinson (2012) call extractive rulers extract everything they can from the populace. They also free themselves and their inner circle of cronies from any obligation to pay tax. There is no social contract in these states to share fairly the burden of paying for things like an education system and a welfare state; the system is one of extraction of obligations imposed on dominated citizens and freedom from obligations by rulers who are the beneficiaries of the extractive institutions. The more extreme the extractive inequality of the tax system becomes, the more likely it is that it will become a major driver of anomie in the society. ${ }^{5}$

\section{Labour market institutions and other institutions of inequality}

This lens on empirical work in the tradition of Messner and Rosenfeld sees egalitarian institutions of welfare and taxation as important. Institutions of the labour market that set a minimum wage that is a living wage for poor families, that take care of employees and their families when they are

5 Extraction, predation and inequality are the issues, not the size of the tax take. Alinaghi and Reed's (2020) meta-analysis of the impact of tax levels on economic growth shows that across 979 estimates of tax effects in Organisation for Economic Co-operation and Development countries a 10 per cent increase in taxes is associated with a decrease in annual GDP growth of -0.2 per cent when bundled as part of a TaxNegative tax-spending-deficit combination. But it is associated with a +0.2 per cent increase in annual GDP growth when part of a TaxPositive fiscal policy package. 
injured at work or become sick, that provide for parental leave when new children are born into workers' families and that guarantee gender and racial equality in the labour market make up another important institution of equality. Particularly important are labour laws that were created under the New Deal and globalised by the International Labour Organization to guarantee the rights for trade unions to organise. These have been significantly deregulated since the 1980s. Their institutional importance arises from the conclusion of Quiggin (2019: 242) that 'the biggest factor determining the distribution of market income is the relative shares going to wages on the one hand and to capital incomes (rent, interest, dividends and capital gains) on the other', combined with the conclusion even of the conservative IMF that ' $[\mathrm{o}] \mathrm{n}$ average, the decline in unionization explains about half of the 5 percentage point rise in the top 10 per cent income share. Similarly, about half of the increase in the Gini of net income is driven by deunionization' (Quiggin 2019: 247).

Many strong economic studies now go to this conclusion. In today's conditions, what that giant of British economists Tony Atkinson (2015) called a 'participation income' is needed. This is based on the principle that everyone has a right to a living income and an obligation to contribute to society. A broader view of contribution to society is needed for a Green New Deal, such as contributions to the arts and volunteering for charities, both of which were enabled by Roosevelt's New Deal. Atkinson advocated the economic benefits of scrapping complex thickets of welfare benefit programs that can be gamed-one pension for the aged, another for people with disabilities, another for one-parent families, and so on-and replacing them with the same basic income guaranteed for everyone not in full-time work. For those in part-time work, the policy design must avoid the poverty trap of high effective marginal tax rates that arrive to deter work as eligibility thresholds are passed. The integration of the tax and welfare systems can be given a gradualism of cut-out of the participation income that avoids such poverty and work incentive traps (see Garnaut 2021).

There are a great many other institutions that make their contribution to the level of inequality in the society. These range from housing policies that go to the affordability of housing — be it public or community housing to gendered rights, to bonus cultures that drive extreme wealth in financial markets that lure traders to defraud people of their savings, to effective 
competition laws and tempered intellectual property protections that are prevented from constituting new forms of monopoly by competition law enforcement (Drahos with Braithwaite 2003).

It can be best for empirical work to focus on overall measures of inequality that summarise the net effects of all the institutions that drive inequality even as the policy responses needed to fix inequality must involve a long march through all these institutions, policy by policy.

Merton's warning about why there will be profound contingency about the effects of poverty and inequality on crime remains of utmost importance. Most people living in conditions of domination decide to accept it, so they can concentrate on the struggle to care for their family. This has been true whether their families lived behind the Iron Curtain in the twentieth century, were oppressed by the exploitative taxes of the British East India Company in eighteenth-century India, lived in chains in the plantation economy of the nineteenth-century American South or on reservations impoverished by ecocide against buffalo and the buffalo economy of First Nations across the Great Plains of North America. We have shown how, when oppressed people do break out of their self-made emotional prison of reconciling their family to its condition of domination, there is no deadly simply mechanics about which of the many inequalities that afflict them might cause crime. The oppressed might follow agitators who rise in violence when the state shuts their local school or hospital, or if the price of fuel rises sharply, when these specificities are only a tiny part of their domination. We saw from Nepal et al.'s (2011) study that when neither levels of poverty nor levels of inequality nationally predict violence, the degree of inequality between local landlords and the peasants of a small community can be a driver of violence.

Hence, from a Mertonian point of view, we might be unimpressed by the endless parade of studies testing the effects of one measure of inequality against another in search of some holy grail of a law of positivist criminology that shows this kind of inequality is the one that matters, and that one is not. This is about studies showing whether the percentage of the population below the poverty line, the rate of longterm unemployment or the Gini coefficient predicts when some other measures do not. The search for an essence of inequality that is the truer driver of a law of criminology may not be the right search. In different places and times, in response to particular historical events, one social 
construction of inequality may be interpreted as oppressive, as a source of hunger that motivates theft of food or the murder of a landlord, and may be most damaging in the dynamics of that context.

Social democratic politics has a good grasp on this. The social democratic political insight is that political and economic institutions must be reformed to progressively reduce all forms of inequality. Republican social democrats who replace inequality with domination through this insight acquire an even better grasp. Because social democrats know that the powerful always fight back rather successfully against all efforts to redistribute wealth and power, they need not waste their time on philosophers' and economists' debates about what is the optimal level of inequality. For the social democrat, in every society that has ever existed, there is too much intersectoral inequality and poverty. If there is historical injustice between the indigenous owners of the land and white settlers, struggle politically to fix it and close the gap; if there is inequality between rich and poor, struggle to reduce it by many means; if there is an oppressed religious minority, struggle politically to lift their oppression; struggle relentlessly to reduce inequality between women and men, LGBTIQ and straight people, between people of one colour and another, and so on, endlessly and without ever ceasing or being satisfied that the good and fair society has finally arrived. If ever it did, it could not last once power again started to beget domination.

This social democratic intuition can be modelled in a more productive kind of quantitative criminology. In ecological studies of crime across census tracts, cities, villages, provinces, war zones or countries, instead of putting, say, poverty, Gini, black-white inequality or caste inequality in an unresolvable contest for the most essential form of inequality to explain crime, put them all in together as one block of inequality variables. ${ }^{6}$ The important question for the social democrat is rightly (in terms of a republican normative theory) to seek to achieve as much reduction

6 Some measures of inequality will have so much multicollinearity with others that it is best to form composite measures to achieve data reduction with as multidimensional a theory as the theory of freedom and crime. But where correlations among different measures of domination are moderate, my preference is to enter them all as a block of variables. The deepest theoretical interest is in the variance explained by the whole block of variables. This is not to deny that there is merit in going on to replace the block with each single variable, in one reanalysis after another, remaining open to some facets of inequality proving more empirically important than others. Extant research suggests these facets will be quite different for explaining crime than for explaining war. This occurs even though the indirect effect on crime mediated through war, and on war mediated through crime, should be important, according to the theory. 
as is politically achievable in the levels of all dimensions of inequality. What we are theoretically interested in is not the explanatory power, the correlation of each facet of inequality, but the multiple correlation of all facets of inequality with crime. So, mirror this normative insight in the explanatory test of the theory of inequality and crime. This is a good example of normative theory improving the power, the sense and the sensibility of explanatory theory.

This approach also problematises the overall summary in Chapter 4 that inequality is the better explanation of crime cross-nationally while poverty is the better explanation of war cross-nationally. I would rather conclude that a social democratically relevant implication of anomie theory is that domination (which encompasses many facets of inequality and poverty) increases the risks of both crime and war, particularly after crime and war cascade into each other (see Chapter 11). The risks arise at many different levels of the oppressive consequences of poverty and inequality depriving people of freedom from dominations such as hunger or an absence of decent education or health services, and the suffering involved in disparate social constructions of the dominations of diverse kinds of inequalities. Inequalities between people with disabilities and the able-bodied are different for vision-impaired people and people without limbs. The numbers of people involved in these different particularities are small, so they will never explain a statistically significant proportion of the variance in crime. Yet the social democratic political intuition is worth taking seriously: we need a well-funded welfare state that embraces repairing the harm of all kinds of domination, including these. If we push this on every front, our aggregated hypothesis is that, in producing a more just society, we will reap the collateral benefit of a more peaceful and less predatory society. At the level of empirical testing, we can capture the dominations of disability in our blocks of measures of inequality and poverty as criminology gets better at measuring the quantity and quality of welfare state guarantees.

\section{Micro-organisational separations of power}

What about the move from the commanding-heights politics of inequality to the micro-drivers of white-collar crime that opened the analysis in Chapter 6? It pointed out what every white-collar crime scholar has known since the first wave of white-collar crime scholarship: that microseparations in organisational life between the power of one corporate 
officer to put an employee on the payroll and the power of another to issue the paycheque must be separated. Why? Because if we fail to do that there will be risks of members of the organisation using 'ghost' employees to enrich themselves. Chapter 6 traversed a wide range of these types of organisational micro-separations of power that reach up to rather higher levels of organisations (which are imperative to white-collar crime prevention). The way crony-capitalist economies work to enrich the few and exploit the rest is through the select group of cronies corrupting a whole gamut of such micro-separations to line their own pockets. Each one might be of modest consequence on its own, but it is the aggregation of the micro to a macro pattern that ultimately criminalises markets and states.

While criminologists need to understand these micro-macro dynamics of organisational domination and crime, we must also have a searing micro-focus on checking and balancing each and all micro illegitimate opportunities one by one. Chapter 10 argues that deft regulatory strategies that lever organisational self-incapacitation are a key policy abstraction for delivering this. Chapter 10 argues that it is difficult and demanding for the regulatory state to accomplish a line of sight into every organisation in an economy and then intervene to plug illegitimate opportunities one by one. Hence, a meta-regulatory strategy to lever self-incapacitation is needed. It delivers regulated self-regulation to incapacitate the exploitation of illegitimate opportunities. Markets in virtue also have a role here.

Consider our Peacebuilding Compared fieldwork on the armed conflict and rule of armed gangs on the streets and neighbourhoods of Guadalcanal in Solomon Islands between 1993 and 2004. Illegal logging in one of the remaining large areas of rainforest on the planet was an important root cause of this violence. It led to criminalisation of the state and armed overthrow of the state driven by illegal logging interests (Braithwaite et al. 2010c). State-building macrostructural remedies were important in Solomon Islands peacebuilding; forestry regulation reform should have been a more important macro-remedy than it was.

Yet, there were micro-elements of logging crime that were usefully remedied through the peace process. Some of the problematic logging was completely illegal, some was completely legal and some was undertaken with a legal licence secured by bribes to political leaders. Some timber could be more cheaply exported through legal shipping contracts; other timber via more expensive illegal shipping. When logs moved on regular 
legal shipping routes, there were customs duties to be paid. Fraud was rife in the customs service here in misrepresenting the value of logs or allowing illegal to be mixed in with legal logs through the payment of a bribe. Often this worked by a low-level employee putting the correct valuation in the customs database. Then a senior customs official in the pay of a political leader would change that valuation. In exchange for peacebuilding investments in improving the training and efficiency of the customs service, foreign donors insisted that new commercial customs software be installed that made it impossible for these practices to continue. Once the new software was installed, the senior officer's electronic signature would be indelibly recorded in the customs database after they changed the valuation of the timber. Audit would track the validity of these changed valuations and the corrupt customs official and their political master would be at risk of criminal conviction.

Let me use this not so trivial micro-separation of powers in Solomon Islands to reinforce the major methodological point about evaluation design that tests blocks of theoretically conceived policy measures rather than putting separately conceived variables in competition, as we saw with the empirics of which is more important: poverty, Gini or racial inequality. Similarly, there is no way that a micro-measure so specific as installing new customs software will predict crime rates in any quantitative comparison. But this customs reform is part of a large bundle of many such micro-reforms called multidimensional peacebuilding, where being multidimensional means being attentive to many of these diverse drivers of illegitimate opportunity structures for the economic predation that feeds armed violence. We have seen in Chapter 6 that the international evidence is that peace operations do work in ending wars and reducing the duration and severity of violence, and that these effect sizes are larger — indeed, they are very large-when these peace operations are multidimensional (Walter et al. 2020). Hence, part of the diagnosis of what is needed at the microlevel for the Solomon Islands peace operation to be effectively multidimensional is software that separates micro-powers to improve customs integrity. In international comparative studies of peace operations, the Solomon Islands peace operation is coded as a highly, though not completely, multidimensional peace operation. And so, at a blocked level of analysis, the customs reform that is ethnographically vindicated in our research (Braithwaite et al. 2010c) is also vindicated through its tiny contribution to macro-quantitative research on peacebuilding multidimensionality. Bovens and Wille (2020) made a helpful methodological contribution to how this might 
be tackled. They argued that to estimate the strength of accountability institutions in a society one would not want to simply count how many of a list of accountability institutions exist in that society. Bovens and Wille (2020) refine 19 measures of the quality of watchdog powers that go beyond the size of inspectorates, budgets and formal powers, to more informal qualitative assessments for each institution, such as its 'salience' (whether its reports grab attention, whether it is a marginal or central player in the accountability landscape), 'credibility' (captured by measures of recognition and legitimacy among the public and stakeholders) and 'creativity' (whether the search is creative for mobilising informal powers when formal powers fail to produce accountability).

\section{Strong business regulatory institutions}

Many countries do not have a national competition authority that enforces what Americans call antitrust laws. Until 1990, most did not, as can be seen in the dynamic model prepared by David Levi-Faur and Jacint Jordana that can be found on my website at johnbraithwaite.com/ regulatory-capitalism/. The majority of regulators in countries that have a national competition regulator are captured by the interests they are supposed to regulate and are quite incapable of credible enforcement action. Hence, to measure this facet of the separation of powers, we must count how many of the key domains of business regulation are covered by adequately resourced regulators with large numbers of street-level inspectors-covering environmental and securities regulation, banking, food, drugs, occupational health and safety, consumer protection, competition, tax enforcement, human rights, discrimination, labour rights, and more. Second, we must code the enforcement credibility for each of these key regulators. Just as the evidence is now encouraging that effective policing reduces crime, so it is that effective street-level regulatory inspection works (Schell-Busey et al. 2016; Braithwaite 2008, 2021f). The difference is that expenditure on policing budgets is popular among politicians, and not only populist politicians. Neoliberal ideology, concern about 'business confidence' and business campaign contributions all make spending on more regulatory inspection much less fiscally favoured by politicians worldwide. The potential for increasing freedom and saving lives by regulatory inspection spending is almost certainly greater than through spending more on police, even though policing is still something that can save a lot of lives when done in an evidence-based way. 
The number of criminal prosecutions a business regulator takes is not the best measure of the enforcement credibility of business regulatory agencies in light of the evidence of Schell-Busey et al.'s (2016) meta-analysis of 58 studies of corporate deterrence (see also Chapter 9). The existence of some big prosecutions that deliver big penalties and big changes in industry practices would be a relevant measure-although that would have to be coded qualitatively by a knowledgeable coder sophisticated in business regulatory realities. Chapter 10 argues that potent incapacitation remedies are more important to corporate crime prevention than long prison sentences or big fines. What is more important still is evidence that the regulator has a strong and continuously improving mix of regulatory sanctions and remedies available to it. That mix is a variable that SchellBusey et al.'s (2016) meta-analysis suggests has an impact alongside formidable inspection.

Braithwaite (2016a) argues and cites evidence that their conclusions about the importance of a mix of strategies would have been even more strongly reached had Schell-Busey et al.'s (2016) outcomes of interest been broadened beyond 'reducing crime' to reducing workplace deaths, reducing environmental harm and similar regulatory outcomes, which are actually the outcomes more commonly and more importantly measured in the policy literature. Usually a measure like workplace deaths is also more important to freedom as nondomination than counts of workplace crimes. An impressive evaluation of stock market regulation by Choi et al. (2016) demonstrates the regulatory strengths that an accountability and integrity branch under a Sun Yat-sen-style constitution might meta-regulate regulators to deliver. Comparisons with controls revealed that a responsively mixed set of strategies is much more effective than having a single punishment or persuasion strategy. Choi et al. (2016) set out to test the effectiveness of the construction between 1992 and 2006 of a responsive regulatory pyramid by the Australian Securities and Investment Commission (ASIC). Choi et al.'s (2016) analysis showed that as successive law reforms progressively equipped ASIC with new layers of more varied arrows in its law-enforcement quiver, the effectiveness of its enforcement progressively increased. A difference-in-differences analysis (to mimic an experimental design) with the impact of New Zealand's securities and financial market regulation as a control reinforced this result. Choi et al. were interested in the effectiveness of securities regulation in making markets more transparent to investors and therefore more efficient and less prone to artificial bubbles that burst. The ASIC 
outcome of concern was whether the market was fully informed. Did regulation produce an improved information environment and market liquidity? Hence, Choi et al. measured the impacts of the Australian and New Zealand financial disclosure regimes by variables such as reduction in financial analysts' forecast errors, forecast dispersion, bid-ask spreads and increases in the turnover rate from the market liquidity test. ASIC's budget and enforcement intensity (measured by prosecution counts) helped analysts to reduce forecast errors for future profits. The responsive regulation effect more strongly increased predictive accuracy over and above those punitive impacts on the integrity of markets. The leverage in such data was formidable, with an Australian sample of 148,498 firmmonth observations (with each observation based on the median for several analysts) and a New Zealand sample of 116,585.

Choi et al.'s (2016) research has the strength of a multiple construct, multimethod move to a pooled time-series, cross-sectional analysis of all major corporations in an economy on an outcome that securities enforcement is designed to deliver, combined with a difference-indifferences analysis of two whole economies. It delivers a larger $n$ of observations than criminological research normally can manage.

\section{Strong markets in crime-control virtue}

Competitive markets in crime-prevention technologies like customs software are important to achieving a low-crime, low-violence society that is freed from corruption and criminalised states. Markets in virtue matter because they deliver the crime-prevention goods along many of the pathways to more richly separated private and public powers. Chapter 7 showed there are many of these virtuous market accomplishments of crime control. Not all of these are familiar to criminologists, though some are, such as reductions in car and bicycle thefts accomplished by locking devices, cybersecurity technologies and a galaxy of security technology markets that have made banks hard targets for anyone who does not own or dominate a bank (Farrell et al. 2014).

\section{Strong civil society}

We can use the Solomon Islands logging crime case study to illustrate the importance of a strongly independent power of civil society that is independent of a criminalised state and a criminalised logging industry. 
Environmental advocacy groups lobbied the leaders of the Solomon Islands peace operation about why illegal logging was not only a major ecological catastrophe, but also a principal driver of the criminalisation of the Solomon Islands state. This had at least some impact in stirring the peace operation into some multidimensional action that included the customs software reforms discussed above. Feminist and church activists had an independent insight into the local secrecy of the problem that revealed another shocking dimension of it. Foreign loggers so economically dominated locales where they logged that they became a law unto themselves. Being above the law allowed them to traffic weapons and other illicit goods such as pornography on logging ships. Not only did they traffic pornography; they also produced it by exploiting indigenous children, according to the systematic research of The Anglican Church of Melanesia (Herbert 2007). It was found that village children were raped, sold into marriage and used for pornography on a remarkably wide scale by foreign loggers. Child prostitution was found in every village visited on the large island of Makira.

A Solomon Islander former logger told Herbert (2007: 25): 'Last year I worked at the camp. There were seven Malaysian men there, and everyone was married to a young girl-[aged] 13 or 14 . They are not interested in the older girls—once they are 18.'

In other words, these crimes beyond the reach of a criminalised state were called to account by feminist church children's advocates. Qualitative coding is best when it can know about the capacity of a civil society actor like the Church of Melanesia to temper power, as opposed to the crudity of counts of the numerical density of NGOs present in a country. Indices of the strength of feminism as a social movement are a particularly strategic facet of civil society strength in this view of measuring what is most important.

\section{Strong social capital}

Evidence that there is an association between social capital broadly conceived and crime, and even more strongly an association between collective efficacy and crime, has been discussed. Robert Sampson and his co-authors make insightful points about why collective efficacy is the most important variant of social capital for crime prevention. Trust alone, for example, is not enough; to really make a difference, trust must be translated into the hands of collective efficacy to prevent, guard, warn or 'pick problems: fix them' (Sparrow 2000). This collective efficacy happens 
on the street (or in the suites, in the case of collective efficacy to prevent corporate crime). With certain more specific types of crime, one could make the claim that, for that kind of crime, recovery capital is more important than collective efficacy. One possible hypothesis could be that the level of investment in recovery capital programs that work would be a better predictor of drug use than collective efficacy.

Some ask whether investment in restorative justice cross-nationally would be a credible predictor of crime. One sensible answer is to think not, at least not in the immediate future, because all societies have some restorative justice programs but in no society does restorative justice approach the status of a mainstream approach to crime. It exists in every country but is a marginal fact on the ground in almost every country. This means its predictive power should be weak. Still, it might be part of a block of 'strength of multidimensional social capital' variables that would include recovery capital and restorative capital measures, social capital variables that could include trust in varied institutions of local, provincial and national government, trust in civil society institutions and trust in business and its institutions. Strong human capital as measured by various Human Development Index variables such as the education of girls cross-nationally is probably best separated from a block of social capital variables.

An interesting question for future empirical work on the freedom theory of crime is that an aggregated measure of reaching the UN Sustainable Development Goals might be a good predictor of crime, war and freedom cross-nationally. Exploring that macrocriminological hypothesis could be a valuable and challenging project. If our principles of crime control are to build freedom, temper power, eliminate poverty and reduce all forms of domination under a just, normative order, I have argued that this implies achieving the UN Sustainable Development Goals. These are: no poverty; zero hunger; good health and wellbeing; quality education; gender equality; clean water and sanitation; affordable and clean energy; decent work and economic growth; industry, innovation and infrastructure; reduced inequalities; sustainable cities and communities; responsible consumption and production; climate action; life below water; life on land; peace, justice and strong institutions; and partnerships for the goals. The UN Sustainable Development Goals enjoy global recognition and consensus. They are not a perfect fit to the criminological theory of this book, but the perfect must not be an enemy of the good in communicating ideas and testing and playing with them. 
More broadly, the theoretical intuition of this section is that a block of multiple social capital formation variables is theoretically what matters more than competition among them.

\section{Strongly separated powers inside the state and inside business}

Based on 25 years of Peacebuilding Compared fieldwork, I am coding a variety of separation of powers ratings (high, medium, low) based on literature on that society that includes its constitution and its law in action, interviews on the ground and relevant quantitative data. They include an evaluation for that society of the separation of the legislature from the executive, the degree to which the electoral system is 'winner takes all' as opposed to one that delivers more proportional legislative balancing, the independence of the judiciary, the independence of the police and separation of the military from involvement in executive government and business. Peacebuilding Compared also codes the density, flourishing and independence of civil society organisations, which include specifically important ones such a free press, free trade unions and independent human rights and women's rights groups for the earlier block of variables representing the strength of civil society. It also codes state capabilities to regulate business, and civil society's capacity to regulate the state. For example, how hard is it in this society for an NGO to win a court case against the government (high, medium, low) and against big business (high, medium, low)? Another code is of what Hood et al. (1999) call Regulation Inside Government. Again, this is a high-medium-low code that is influenced in the rating of its level (before and after conflict) for Solomon Islands coding, for example, by fieldwork knowledge of the little customs reform mentioned above, drawn to our attention in interviews with peacebuilders, ministers responsible for customs and former prime ministers and officials of the customs agency itself. Then there are more objective variables based on codes of whether the state has an ombudsman, an independent audit office, an independent civil service commission, an anticorruption commission and what their budgets, powers and independence look like. Other variables go to human rights enforcement capabilities. Another set of Peacebuilding Compared qualitative separation of powers codes (pre-conflict and post-conflict) included: 
- Is there a rich separation of powers between the judiciary and the rest of the state?

- Is there a rich separation of powers between prosecutors and the rest of the state?

- Is there a rich separation of powers between the police and the rest of the state?

- Is there a strong separation of the police and military from involvement in business (protection rackets count as involvement)?

- How politically powerful is the intelligence service(s)?

- Is there a rich and plural separation of powers between accountability institutions such as the ombudsman, auditor-general, inspectorgeneral, civil service board, anticorruption commission and the rest of the state?

- Do some elites enjoy impunity from the rule of law?

- How strong are parliamentary institutions compared with the executive?

- Does the separation of powers create so much interference by one branch into the affairs of another that branches of governance have insufficient autonomy and discretion to be responsive to the needs of citizens?

- Is freedom to protest in the streets secured by the rule of law?

- How potent is anti-monopoly legislation?

- How monopolised/cartelised is the economy?

Peacebuilding Compared codes a considerable number of additional separations of powers variables beyond these. The aim is not to use each as an independent variable on its own but to include it in scales of blocked variables that measure, for example, 'strongly separated powers inside the state' and 'strongly separated powers inside business'. Again, the theory advanced is that any one of these policy measures is a thin reed for changing much on its own but, woven together, a clutch of thin reeds could have strength in the binding together of their weaknesses. This is not a theoretical intuition plucked from thin air. It is grounded in an appreciation of the empirical findings discussed in previous chapters that multidimensional peacekeeping works better than unidimensional peacekeeping, that problem-oriented policing works as a policy that plays out with many disparate dimensions of problem solving even though one particular street-lighting intervention might not work at all, 
that motivational interviewing works as a recovery capital intervention that follows unknowable and diverse individualised paths. The multidimensionality of motivational interviewing is so robust it can have some effectiveness in delivering recovery in the hands of practitioners who fail to grasp and implement most motivational interviewing principles (Best et al. 2009; Miller 2007)!

Through all of the above the hope is to have shown that it is possible to give more institutional meaning to Messner and Rosenfeld's idea of strong institutions of the polity that temper the power of markets. Messner and Rosenfeld have already admirably demonstrated the operationalisability and power of strong institutions of the family, education, welfare and religion. This book seeks to go beyond that to argue that macrocriminology can operationalise through blocks of more micro and meso variables the ideas of strong markets, a strong state and strong civil society, strong separations of public powers, strong separations of private powers, strong enculturation of trust and strong institutionalisation of distrust, strong economic capital, strong human capital and strong social capital. Together, this ensemble of strengths can form a resilient republican fabric that delivers freedom from domination and crime. Or so I hypothesise.

The empirical testing strategy for such a republican theory of crime control and freedom would involve, at a conceptual level, the stepwise addition of blocks of correlated variables with an institutional character, more than adding single variables. It would be bound to involve a mix of both.

\section{What about strong individuals?}

I am insufficiently the psychologist to have clear views about how to measure cross-national differences in the strengths of individuals. Dominated individuals include those who would never speak up in a critical voice to their boss and who always do what a patriarch, a parent or delinquent peers tell them to do even if that is an unhealthy choice. Dominated individuals can be enslaved-and even prefer to be a slave than to be free by speaking truth to power. Measuring the strength of individuals across societies by their suicide rates seems unsatisfactory. There may be circumstances in which suicide is enacted as a kind thing one can do for one's family and an individual must be strong to do it. 
Susanne Karstedt has used Hofstede's cross-cultural study of a values scale that measures individualism, showing that in societies with high individualism, interpersonal lethal violence is lower (Karstedt 2006), as is state violence (Karstedt 2011b), corruption and organised crime (Karstedt 2012b). Smith and Robinson (2019) found bullying victimisation was lower among school-aged children in individualist societies. One of the problems with Hofstede's individualism as a measure of the strength of individuals is that one can endorse Hofstede's item 'Group success is more important than individual success' while being an amazing individual success. This indeed is what sporting coaches always say: if you want to become the biggest star on the team, play for group success rather than individual success. Likewise, you can have the strongest possible capacity to achieve and commitment to your individual goals while agreeing that 'Employees should pursue their goals after considering the welfare of the group'. Nevertheless, variants of Hofstede's individualism scale may be one option for the strength of individuals across societies.

At the end of the day, republicanism is about liberating individuals. No great social movement for freedom ever took off without the strength and self-efficacy of catalytic individuals who initially were small in number. For all that, I am content for the moment to be the macrocriminologist who sees strong individuals as being constituted by their own agency, by strong families, strong welfare rights (such as to secure housing), guarantees against being born into poverty, a strong healthcare system, communities with collective efficacy, strong recovery, restorative and relational capital, strong schools and human development in workplaces and strong women's rights—all enabled by the enculturation of trust and collective hope.

\section{Conclusion}

Braithwaite et al. (2012) studied the 1999 triumph of networked tempering of tyranny in Timor-Leste by inspiring social democratic leaders with pro-freedom values like Xanana Gusmão and José RamosHorta. After decades of war, domination and criminalisation, a peaceful, free, low-crime society was created. Through this national case study, we have been able to grasp the many blocks of variables and individual variables that can be specified in tests of the theory of freedom and crime, or simply in an elaborated and integrated version of classical and 
institutional anomie theory. The conclusion to Chapter 2 summarised how these variables and blocks of variables could be layered into some kind of stepwise quantitative test of the theory of crime and freedom on cross-national data on homicide rates, corruption levels, the size of the black market and other crime outcomes. Historical and ethnographic research based on more studies such as this one of Timor-Leste, and other studies of more global sweep such as Peacebuilding Compared, will also refute and revise the key propositions of the theory of crime and freedom in the decades ahead.

Braithwaite et al. (2012) wrote a story of how quickly the government led by exceptional Timor-Leste leaders became corrupted and criminalised. This happened because they excluded the very civil society networks that brought them to power. With equal historical speed, however, these civil society networks regrouped, independent journalism spoke truth to power, the UN transitional administration helped to resurrect constitutional checks and balances, UN peacekeeping worked (Walter et al. 2020). Priests and nuns protested from pulpits and on the streets and marginalised indigenous elders from remote villages brought the ancestors to the capital to discipline wayward national leaders in national rituals of restorative justice.

Good constitutions enable tempered power by separating and balancing powers. They also enable power to be decisive in accomplishing specialised purposes efficiently and semi-autonomously. Each power is channelled to its specialised purposes by checks and balances from other powers that prevent them from arbitrarily breaking the banks of their channel. The Timor-Leste case study illustrates how contestation, dialogue and science have important roles in channelling power to good purposes, away from arbitrary excess. When police intelligence tortured suspects claiming this saved lives, citizens rose up to contest arbitrary authority for the police to punish. Debate about the propriety of police jumping outside their authorised channels of prevention and arrest occurred in the Timor-Leste legislature. Prosecutors monitored the debate and threatened police with assault charges. The UN transitional administration was a channel of good policy science that disputed assertions that torture was a way to prevent terrorism and coups. Many other terrible tyrannies occurred along this fraught historical journey, however. 
Adjusting channels that empower the legitimate exercise of power is fundamental to states, businesses and societies having the capacity to grow freedom and prevent crime. Acemoglu and Robinson (2019: 270) illustrate the problem of inept articulation of rules of state power with the impoverished Indian state of Bihar. Bihar would receive money from the national government, but then fail to spend it because any spending of more than US $\$ 55,000$ had to be approved by the state cabinet, which could not wade through the backlog of decisions this mandated!

Nodal power in civil society networks has a crucial role in coordinating, bridging and linking capital among the separated powers of a democracy to tame rogue power. Without networked governance of tyranny led from civil society, there can be no freedom. Criminalised states and criminalised markets evolve unless there is networked governance of their tyranny. Social democratic leaders in Timor-Leste who embodied civic republican values of nondomination proved as vulnerable to criminalised state power as the brutal occupation they had supplanted when this networked governance of tyranny from civil society was pushed and fell away. Reliance on a revered pro-freedom leadership governing under a new pro-freedom constitution destroyed freedom. Then the brave people of Timor-Leste, still recovering from the trauma of the genocide that had been attempted against them, reorganised in a nodal way in civil society after 2006. They realised that democracy and nondomination are not things you put in place with a shiny new constitution and trusted leaders. They are things you lose if you fail to struggle continuously for them through civil society networks.

Perhaps as much as one-fifth of the Timor-Leste population lost their lives because of the violent occupation by Indonesia that ended in 1999. According to UNODC, the homicide rate in Timor-Leste was down to 12 per 100,000 per year in 2003-06, then halved by 2007, according to the World Bank, and halved again between 2007 and 2009 to become a country with a below-average homicide rate. Today, the gang violence that was out of control until 2006 is overwhelmingly pacified; TimorLeste is a comparatively low-crime democracy, although perhaps not a model democracy in many ways. It still suffers its dominations. In 2020, it worsened on the Transparency International corruption perceptions list to 86 of 198 countries. Then again, few, if any, of the countries with a worse ranking were recovering from the level of domination and violent 
death per capita that Timor-Leste had suffered in the final decades of the twentieth century. Overall, its journey since 1999 has been determinedly towards freedom and away from cascading violence and crime.

Sun Yat-sen's constitutional innovation of an elected accountability and integrity branch of governance that is independent of the judiciary, legislature and executive and has impeachment authority over them is a profound contribution to republican thinking about securing freedom and preventing crime. This chapter has sought to argue that constitutionalism is important to the macrocriminological pursuit of a low-crime society. But sadly, unlike the South Koreans, the western constitutional imagination is bogged in western ruts that have given up on the idea that it is possible to impeach a president, a prime minister, or a chief justice. Westerners do not understand why the Thai students leading the protests on the streets of Bangkok at the time of writing have a bigger vision. It is a vision for the character of the people's struggle for a new people's constitution to restore freedom and tame a criminalised state and criminalised markets. 
This text is taken from Macrocriminology and Freedom, by John Braithwaite, published 2022, The Australian National University, Canberra, Australia.

doi.org/10.22459/MF.2021.08 